\title{
BIST Menkul Kıymet Yatırım Ortaklıkları Endeksinde (XYORT) Yer Alan İşletmelerin Finansal Performanslarının Entropi ve Gri İlişkisel Analiz Bütünleşik Yaklaşımı İle Değerlendirilmesi
}

\author{
Ejder AYÇİN ${ }^{1}$ \\ $\ddot{O} \mathbf{z}$
}

İsletme performansinın en önemli göstergelerinden biri olan finansal performansin doğru bir şekilde ölçülmesi, işletmelerin gelecekteki karar verme süreçleri için önem arz etmektedir. Bu çalışmanın amacı Borsa İstanbul'da (BIST) menkul klymet yatırım ortakllkları endeksinde yer alan işletmelerin finansal performansların değerlendirmektir. Bu doğrultuda, belirlenen finansal performans kriterlerine ilişkin önem ăğrllklarl, objektif bir değerlendirme tekniği olan Entropi yöntemiyle hesaplanmıştır. Uygulama kapsamindaki işletmelerin performanslar ise Gri İlişkisel Analiz yöntemiyle değerlendirilmişstir. Uygulama sonuçları Entropi ve Gri İlişkisel Analiz yöntemlerinden oluşan bütünleşik bu yaklaşımın, finansal performansın değerlendirilmesinde karar vericilere yardımcı olacağın göstermiştir.

Anahtar Kelimeler: Finansal Performans, Çok Kriterli Karar Verme, Entropi, Gri İlişkisel Analiz

Jel Sinıflandirma Kodları: C44, L25

\section{Evaluation of the Financial Performances of Enterprises in the BIST Securities Investment Trusts Index (XYORT) using Entropy and Grey Relational Analysis Integrated Approach}

\begin{abstract}
Accurate measurement of financial performance, which is one of the most important indicators of operational performance, is important for the future decision-making processes of enterprises. Evaluating the financial performance of enterprises included in the index of securities investment trusts in BIST is the purpose of this study. In this respect, the significance weights regarding the determined financial performance criteria were calculated by Entropy method which is an objective evaluation technique. The performances of the enterprises within the scope of the application were evaluated by Grey Relational Analysis method. The results of the application showed that this integrated approach consisting of Entropy and Grey Relational Analysis methods will help decision makers in evaluating financial performance.
\end{abstract}

Keywords: Financial Performance, Multi Criteria Decision Making, Entropy, Grey Relational Analysis

Jel Classification Codes: C44, L25

\footnotetext{
${ }^{1}$ Dr. Öğr. Üyesi, Munzur Üniversitesi, İktisadi ve İdari Bilimler Fakültesi, İşletme Bölümü, eaycin@munzur.edu.tr
} 


\section{E. AYÇIN}

\section{GİRIŞ}

Finansal piyasalardaki aktörlerden biri olan tasarruf sahipleri sahip oldukları tasarruflarını, şirketlerden, yatırım kuruluşlarından ve ya menkul kıymet borsalarından ortaklıkların paylarını ve tahvil almak suretiyle değerlendirebilirler. Bireysel birikimlerin yeterli büyüklükte olmamasından kaynaklanacak risk ortamının olması, yatırım yapma sürecindeki bilgi eksikliği ve uzmanlık gerektiren bir yapıya ihtiyaç duyulması nedenleriyle, sermaye piyasası tarafindan kollektif yatırım kuruluşları olarak adlandırılan, yatırım fonları ve menkul kıymet yatırım ortaklıkları geliştirilmiştir (SPK,2016).

Menkul kıymet yatırım ortaklıkları tasarruf sahiplerinin birikimlerini, farklı menkul kıymetlerden oluşan bir portföy yaratarak değerlendiren ve bu yolla elde ettikleri kazançları payları oranında ortaklarına dağıtan işletmelerdir. $\mathrm{Bu}$ işletmelerin performanslarının yüksek olması ve faaliyetlerinin sürdürülebilirliği, tasarruflarını bu işletmeler ile değerlendiren tasarruf sahipleri için oldukça önemlidir. Bu açıdan bakıldığında bu işletmelerin finansal performanslarının ortaya koyulmasının önemi ve gerekliliği, bu çalışmanın çıkış noktasını oluşturmaktadır.

İşletmelerin finansal performanslarının değerlendirilmesi, içerisinde birçok kriteri bulunduran bir süreç olarak karşımıza çıkmaktadır. Dolayısıyla bu çalışmada BIST menkul kıymet yatırım ortaklı̆̆ endeksinde yer alan işletmelerin finansal performanslarının değerlendirilmesinde çok kriterli karar verme (ÇKKV) yöntemlerinden yararlanılmıştır. Öncelikle finansal performans kriterlerinin belirlenmesi amacıyla kapsamlı bir literatür taraması gerçekleştirilmiştir. Aynı zamanda kriterlerin çalışmanın amacına uygunluğunun da belirlenmesi için, yatırım uzmanlarının görüşlerinden de yararlanılmıştır. Belirlenen performans kriterlerinin önem ağırlıkları, objektif bir kriter ağırlıklandırma yöntemi olan Entropi yöntemiyle hesaplandıktan sonra, uygulama kapsamında yer alan işletmelerin finansal performansları Gri İlişkisel Analiz yöntemiyle analiz edilerek, işletmelere ilişkin sıralama elde edilmiştir. 


\section{LITERATÜR TARAMASI}

Finansal performansın ÇKKV yöntemleri kullanılarak değerlendirilmesi konusunda, hem uluslararası hem de ulusal literatürde birçok çalışmaya rastlanmıștır. $\mathrm{Bu}$ çalıșmalarda kullanılan yöntemler ve ele alınan finansal performans değerlendirme kriterlerine yönelik bir özet, Tablo 1'de sunulmuştur.

Tablo 1. Literatür Taraması

\begin{tabular}{|c|c|c|}
\hline Yazar(lar) & Finansal Performans Kriterleri & $\begin{array}{l}\text { Kullanılan } \\
\text { Yöntemler }\end{array}$ \\
\hline $\begin{array}{l}\text { Ho ve Wu } \\
(2006)\end{array}$ & $\begin{array}{l}\text { Karlılık, kaldıraç, likidite, ekonomik yapı ve } \\
\text { büyüme oranları }\end{array}$ & Gri İliş̧kisel Analiz \\
\hline $\begin{array}{l}\text { Wang } \\
(2008)\end{array}$ & $\begin{array}{l}\text { Finansal yapı, ödeme gücü, ciro ve karllılı ana } \\
\text { kriterleri ve finansal oranlardan oluşan alt } \\
\text { kriterler }\end{array}$ & $\begin{array}{l}\text { Gri İlişkisel Analiz } \\
\text { ve Bulanık } \\
\text { TOPSIS }\end{array}$ \\
\hline $\begin{array}{l}\text { Ertuğrul ve } \\
\text { Karakaşoğlu } \\
\text { (2009) }\end{array}$ & $\begin{array}{l}\text { Likidite oranları, faaliyet oranları, ekonomik yap1 } \\
\text { oranları, karlılık oranları ve büyüme oranları }\end{array}$ & $\begin{array}{l}\text { Bulanık AHP ve } \\
\text { TOPSIS }\end{array}$ \\
\hline $\begin{array}{l}\text { Wang } \\
(2009)\end{array}$ & $\begin{array}{l}\text { Finansal yap1, ödeme gücü, ciro ve karlılık ana } \\
\text { kriterleri ve finansal oranlardan oluşan alt } \\
\text { kriterler }\end{array}$ & $\begin{array}{l}\text { Bulanık Gri } \\
\text { İlişkisel Analiz }\end{array}$ \\
\hline $\begin{array}{l}\text { Seçme vd. } \\
(2009)\end{array}$ & $\begin{array}{l}\text { Sermaye yeterliliği, varlık kalitesi, likidite, } \\
\text { karlılık, gelir yapısı ve hisse durumu }\end{array}$ & $\begin{array}{l}\text { Bulanık AHP, } \\
\text { TOPSIS }\end{array}$ \\
\hline $\begin{array}{l}\text { Wang ve } \\
\text { Lee }(2010)\end{array}$ & $\begin{array}{l}\text { Finansal yapı oranları, ödeme gücü oranları, ciro } \\
\text { oranları ve karlılık oranları }\end{array}$ & $\begin{array}{l}\text { Bulanık Gri } \\
\text { İlişkisel Analiz }\end{array}$ \\
\hline $\begin{array}{l}\text { Akyüz vd. } \\
(2011)\end{array}$ & Likidite, finansal yap1, faaliyet ve karlılık oranları & TOPSIS \\
\hline $\begin{array}{l}\text { Bülbül ve } \\
\text { Köse (2011) }\end{array}$ & $\begin{array}{l}\text { Cari oran, likidite oranı, nakit oran, toplam borç/ } \\
\text { toplam aktif oranı, aktif karlılığı, satış karlılığı, } \\
\text { özsermeye karlılığı ve net satışlar/toplam aktif } \\
\text { oranı }\end{array}$ & $\begin{array}{l}\text { ELECTRE ve } \\
\text { TOPSIS }\end{array}$ \\
\hline $\begin{array}{l}\text { Peker ve } \\
\text { Baki (2011) }\end{array}$ & Likidite, karlılık ve kaldıraç oranları & Gri İlişkisel Analiz \\
\hline $\begin{array}{l}\text { Kung vd. } \\
\text { (2011) }\end{array}$ & $\begin{array}{l}\text { Cari oran, borç oranı, özsermaye/borç oranı, satış } \\
\text { karlılık oranı, aktif karlılık oranı ve vergi öncesi } \\
\text { kar }\end{array}$ & $\begin{array}{l}\text { Bulanık AHP ve } \\
\text { Bulanık TOPSIS }\end{array}$ \\
\hline $\begin{array}{l}\text { Balezentis } \\
\text { vd. (2012) }\end{array}$ & $\begin{array}{l}\text { Satış karı, aktif karlılık oranı, kaldıraç oranı, cari } \\
\text { oran, alacak devir hızı oranı ve özsermaye karlılık } \\
\text { oranı }\end{array}$ & $\begin{array}{c}\text { Bulanık VIKOR, } \\
\text { Bulanık TOPSIS } \\
\text { ve Bulanık ARAS } \\
\end{array}$ \\
\hline $\begin{array}{l}\text { Elitaş vd. } \\
(2012)\end{array}$ & Likidite, kaldıraç ve karlılık oranları & Gri İlişkisel Analiz \\
\hline
\end{tabular}




\section{E. AYÇİN}

Tablo 1. Literatür Taraması (Devamı)

\begin{tabular}{|c|c|c|}
\hline Yazar(lar) & Finansal Performans Kriterleri & $\begin{array}{l}\text { Kullanılan } \\
\text { Yöntemler }\end{array}$ \\
\hline $\begin{array}{l}\text { Ignatius vd. } \\
(2012)\end{array}$ & $\begin{array}{l}\text { Satış büyüklüğü, aktif karlılık oranı, öz sermaye } \\
\text { karlılık oranı, cari oran ve varlık devir hızı }\end{array}$ & PROMETHEE II \\
\hline $\begin{array}{l}\text { Lee vd. } \\
(2012)\end{array}$ & $\begin{array}{l}\text { Likidite, karlılık, yatırımın geri dönüşü, etkinlik, } \\
\text { finansal kaldıraç ve nakit akışı ana kriterleri ve } \\
\text { altında yer alan alt kriterler }\end{array}$ & $\begin{array}{l}\text { Entropi ve Gri } \\
\text { İlişkisel Analiz }\end{array}$ \\
\hline $\begin{array}{l}\text { Özden vd. } \\
(2012)\end{array}$ & $\begin{array}{l}\text { Cari oran, alacak devir süresi, stok devir süresi, } \\
\text { ticari borç devir süresi, borçlanma oranı, } \\
\text { özsermaye karlılığı, esas faaliyet kar marjı ve } \\
\text { faaliyet maliyet oranı }\end{array}$ & VIKOR \\
\hline $\begin{array}{l}\text { Yalçın vd. } \\
(2012)\end{array}$ & $\begin{array}{l}\text { Varlık karlılığı, özsermaye karlılığı, hisse başına } \\
\text { karlılık, F/K oranı, ekonomik katma değer, } \\
\text { piyasa katma değeri, nakit katma değeri ve } \\
\text { yatırımın nakit karlılığı }\end{array}$ & $\begin{array}{l}\text { Bulanık AHP, } \\
\text { VIKOR ve TOPSIS }\end{array}$ \\
\hline Doğan (2013) & $\begin{array}{l}\text { Likidite, kaldıraç, varlık kalitesi ve karlılık } \\
\text { oranları }\end{array}$ & Gri İlişkisel Analiz \\
\hline $\begin{array}{l}\text { Ecer ve } \\
\text { Günay (2014) }\end{array}$ & $\begin{array}{l}\text { Likidite, finansal yap1, faaliyet ve karlılık } \\
\text { oranları }\end{array}$ & Gri İlişkisel Analiz \\
\hline Ergül (2014) & $\begin{array}{l}\text { Cari oran, likidite oranı, borç oranı, duran varlık/ } \\
\text { uzun vadeli borçlar oranı, SMM/ ortalama stok } \\
\text { oranı, faaliyet oranları ve karlılık oranları }\end{array}$ & $\begin{array}{l}\text { ELECTRE ve } \\
\text { TOPSIS }\end{array}$ \\
\hline $\begin{array}{l}\text { Esbouei vd. } \\
(2014)\end{array}$ & $\begin{array}{l}\text { Aktif karlılığı, özsermaye karlılığı, F/K oranı, } \\
\text { ekonomik katma değer, piyasa katma değeri, } \\
\text { nakit katma değer, gerçek katma değer, Tobin's } \\
\text { Q endeksi ve hissedar değeri }\end{array}$ & $\begin{array}{l}\text { Bulanık ANP ve } \\
\text { Bulanık VIKOR }\end{array}$ \\
\hline $\begin{array}{l}\text { Ghadikolaei } \\
\text { vd. (2014) }\end{array}$ & $\begin{array}{l}\text { Aktif karlılığı, özsermaye karlılığı, F/K oranı, } \\
\text { ekonomik katma değer, piyasa katma değeri, } \\
\text { nakit katma değer, gerçek katma değer, Tobin's } \\
\text { Q endeksi ve hissedar değeri }\end{array}$ & $\begin{array}{l}\text { Bulanık AHP, } \\
\text { Bulanık VIKOR, } \\
\text { Bulanık ARAS, } \\
\text { Bulanık COPRAS }\end{array}$ \\
\hline $\begin{array}{l}\text { Mandic vd. } \\
(2014)\end{array}$ & $\begin{array}{l}\text { Özsermaye, portföy, kaynaklar, likit varlıklar, } \\
\text { nakit akışı, net faiz geliri, vergi öncesi kar ve ana } \\
\text { faaliyet geliri }\end{array}$ & $\begin{array}{l}\text { Bulanık AHP ve } \\
\text { TOPSIS }\end{array}$ \\
\hline $\begin{array}{l}\text { Ömürbek ve } \\
\text { Mercan } \\
(2014)\end{array}$ & $\begin{array}{l}\text { Cari oran, nakit oranı, yabancı kaynaklar/toplam } \\
\text { aktif oranı, stok devir hızı, özkaynak devir hızı, } \\
\text { karlılık oranları ve smm/net satışlar oranı }\end{array}$ & $\begin{array}{l}\text { TOPSIS ve } \\
\text { ELECTRE }\end{array}$ \\
\hline $\begin{array}{l}\text { Saldanlı ve } \\
\text { Sirma (2014) }\end{array}$ & $\begin{array}{l}\text { Cari oran, nakit oran, kaldıraç oranı, finansman } \\
\text { giderleri/toplam borç oranı, aktif devri hızı, } \\
\text { özsermaye devir hızı, aktif karlılığı ve özsermaye } \\
\text { karlılığı }\end{array}$ & TOPSIS \\
\hline
\end{tabular}


Tablo 1. Literatür Taraması (Devamı)

\begin{tabular}{|c|c|c|}
\hline $\begin{array}{l}\text { Shen ve } \\
\text { Tzeng (2014) }\end{array}$ & $\begin{array}{l}\text { Sermaye yeterliliği, varlık kalitesi, kazanç ve } \\
\text { karlılık, likidite, faiz oranı duyarlılığı, büyüme } \\
\text { ana kriterleri ve bu kriterlerin altında yer alan alt } \\
\text { kriterler }\end{array}$ & $\begin{array}{l}\text { RSA, DRSA, } \\
\text { DEMATEL } \\
\text { Tabanlı ANP ve } \\
\text { VIKOR }\end{array}$ \\
\hline $\begin{array}{l}\text { Tayyar vd. } \\
\text { (2014) }\end{array}$ & Likidite, mali yapı, faaliyet ve karlılık oranları & $\begin{array}{c}\text { AHP ve Gri } \\
\text { İlişkisel Analiz }\end{array}$ \\
\hline Wang (2014) & $\begin{array}{l}\text { Finansal yapı, ciro, karlılık ve borç ödeme } \\
\text { yeteneği ana kriterleri ve alt kriterler }\end{array}$ & $\begin{array}{l}\text { Bulanık TOPSIS ve } \\
\text { Gri İlişkisel Analiz }\end{array}$ \\
\hline $\begin{array}{l}\text { Hsu vd. } \\
(2015)\end{array}$ & $\begin{array}{l}\text { Faaliyet kabiliyeti, ödeme gücü yeteneği ve } \\
\text { karlılık ana kriterleri ve alt kriterler }\end{array}$ & $\begin{array}{l}\text { Gri İlişkisel Analiz } \\
\text { ve TOPSIS }\end{array}$ \\
\hline İç vd. (2015) & $\begin{array}{l}\text { Likidite, finansal yap1, faaliyet ve karlılık } \\
\text { oranları }\end{array}$ & $\begin{array}{l}\text { TOPSIS, Gri } \\
\text { İlişkisel Analiz, } \\
\text { MOORA ve } \\
\text { VIKOR }\end{array}$ \\
\hline $\begin{array}{l}\text { İslamoğlu vd. } \\
(2015)\end{array}$ & $\begin{array}{l}\text { Likidite, kaldıraç, varlık ve sermaye yapısı, ciro } \\
\text { ve karlılık ana kriterleri ve alt kriterler }\end{array}$ & Entropi ve TOPSIS \\
\hline $\begin{array}{l}\text { Kazan vd. } \\
(2015)\end{array}$ & $\begin{array}{l}\text { Büyüme oranları, değer oranları, finansal yapı } \\
\text { oranları, faaliyet oranları, karlılık oranları ve } \\
\text { likidite oranları }\end{array}$ & $\begin{array}{c}\text { AHP, } \\
\text { PROMETHEE }\end{array}$ \\
\hline $\begin{array}{l}\text { Yükçü ve } \\
\text { Kaplanoğlu } \\
(2015)\end{array}$ & $\begin{array}{l}\text { Borç ödeme gücü, karlılık, faaliyet kapasitesi, iş } \\
\text { geliştirme kapasitesi, yapısal sağlamlık ve } \\
\text { sermaye artırma kapasitesi ana kriterleri ve } \\
\text { bunlara ilişkin alt kriterler }\end{array}$ & $\begin{array}{l}\text { MOORA, TOPSIS, } \\
\text { VIKOR, Gri } \\
\text { İlişkisel Analiz }\end{array}$ \\
\hline $\begin{array}{l}\text { Chang ve } \\
\text { Tsai (2016) }\end{array}$ & $\begin{array}{l}\text { Hizmet, performans, profesyonellik, risk } \\
\text { kontörlü ve güven ana kriterleri ve alt kriterler }\end{array}$ & AHP ve VIKOR \\
\hline $\begin{array}{l}\text { Erdoğan vd. } \\
(2016)\end{array}$ & $\begin{array}{l}\text { Likidite, finansal yapı, faaliyet ve karlılık } \\
\text { oranları }\end{array}$ & $\begin{array}{l}\text { TOPSIS, VIKOR } \\
\text { ve ELECTRE }\end{array}$ \\
\hline $\begin{array}{l}\text { Meydan vd. } \\
(2016)\end{array}$ & $\begin{array}{l}\text { Likidite, finansal yapı, faaliyet ve karlılık } \\
\text { oranları }\end{array}$ & Gri İlişkisel Analiz \\
\hline $\begin{array}{l}\text { Ömürbek vd. } \\
(2016)\end{array}$ & $\begin{array}{l}\text { Sermaye, hisse senedi, piyasa değeri, satış geliri, } \\
\text { personel sayısı, net kar marjı, cari oran, } \\
\text { özsermaye karlılığı, satışların karlılığ1 ve net } \\
\text { satışlar/personel sayısı oranı }\end{array}$ & $\begin{array}{l}\text { Entropi, MAUT ve } \\
\text { SAW }\end{array}$ \\
\hline $\begin{array}{l}\text { Ömürbek ve } \\
\text { Eren (2016) }\end{array}$ & $\begin{array}{l}\text { Cari oran, nakit oran, asit test oranı, } \\
\text { stoklar/toplam aktif, öz kaynak/toplam aktif, } \\
\text { borçlanma oranı, finansal kaldıraç oranı, öz } \\
\text { kaynak karlılığı, net kar marjı, fiyat kazanç } \\
\text { oranı, net çalışma sermayesi devir hızı, stok } \\
\text { devir hızı ve alacak devir hızı }\end{array}$ & $\begin{array}{l}\text { PROMETHEE, } \\
\text { MOORA ve } \\
\text { COPRAS }\end{array}$ \\
\hline $\begin{array}{l}\text { Wanke vd. } \\
(2016)\end{array}$ & $\begin{array}{l}\text { Sermaye yeterliliği, varlık kalitesi, yönetim, } \\
\text { karlılık, likidite ve piyasa riskine karşı duyarlılık } \\
\text { ana kriterleri ve alt kriterler }\end{array}$ & $\begin{array}{c}\text { Bulanık AHP ve } \\
\text { TOPSIS }\end{array}$ \\
\hline
\end{tabular}




\section{E. AYÇİN}

Tablo 1. Literatür Taraması (Devamı)

\begin{tabular}{|c|c|c|}
\hline $\begin{array}{l}\text { Akçakanat } \\
\text { vd. (2017) }\end{array}$ & $\begin{array}{l}\text { Toplam aktifler, toplam krediler ve alacaklar, } \\
\text { toplam mevduat, özkaynak toplamı, şube ve } \\
\text { personel sayısı }\end{array}$ & $\begin{array}{l}\text { Entropi ve } \\
\text { WASPAS }\end{array}$ \\
\hline $\begin{array}{l}\text { Aytekin ve } \\
\text { Karamaşa } \\
(2017)\end{array}$ & $\begin{array}{l}\text { Cari oran, çok sınırlı likidite oranı, borç oranı, } \\
\text { satışların karlılığı, özsermaye karlılığı ve } \\
\text { yatırımın geri dönüşü }\end{array}$ & $\begin{array}{l}\text { Shannon Entropisi } \\
\text { ve TOPSIS }\end{array}$ \\
\hline $\begin{array}{l}\text { Orçun ve } \\
\text { Eren }(2017)\end{array}$ & $\begin{array}{l}\text { Likidite oranları, aktif devir hızı, kaldıraç, } \\
\text { özsermaye devir hızı, satışların karlılık, } \\
\text { özsermaye karlılık, esas faaliyet karlılık oranları }\end{array}$ & TOPSIS \\
\hline $\begin{array}{l}\text { Önder ve } \\
\text { Altıntaş } \\
(2017)\end{array}$ & $\begin{array}{l}\text { Varlık büyüme oranı, maliyet/net satış oranı, } \\
\text { aktif karlılığı, net kar marjı, özsermaye karlılığ1, } \\
\text { cari oran, asit-test oran ve duran varlık/toplam } \\
\text { varlık oranı }\end{array}$ & $\begin{array}{l}\text { ANP ve Gri } \\
\text { İlişkisel Analiz }\end{array}$ \\
\hline $\begin{array}{l}\text { Ünlü vd. } \\
(2017)\end{array}$ & $\begin{array}{l}\text { Özsermaye karlılığ1, aktif karlılığı, satışların } \\
\text { karlılığı, faaliyet nakit akımı/varlık toplamı, } \\
\text { piyasa katma değeri, yatırımın nakit karlılığı ve } \\
\text { nakit katma değer }\end{array}$ & Critic ve TOPSIS \\
\hline $\begin{array}{l}\text { Ege ve } \\
\text { Yaman } \\
(2018)\end{array}$ & $\begin{array}{l}\text { Aktif karlılığı, alacak devir hızı oranı, toplam } \\
\text { borç oranı, bor./özsermaye oranı, cari oran, F/K } \\
\text { oranı, pay başına kazanç oranı, özsermaye } \\
\text { karlılığ1, PD/DD oranı ve stok devir hızı oranı }\end{array}$ & $\begin{array}{l}\text { TOPSIS ve } \\
\text { MOORA }\end{array}$ \\
\hline $\begin{array}{l}\text { Erdoğan ve } \\
\text { Yamaltdinova } \\
(2018)\end{array}$ & $\begin{array}{l}\text { Likidite, finansal yapı, devir hızı ve karlılık } \\
\text { oranları }\end{array}$ & TOPSIS \\
\hline $\begin{array}{l}\text { Gök Kısa ve } \\
\text { Perçin (2018) }\end{array}$ & $\begin{array}{l}\text { Net satışlar, varlıklar, piyasa değeri, çalışan } \\
\text { sayısı, kaldıraç oranı, aktif karlılığı ve net kar } \\
\text { marjı }\end{array}$ & Entropi ve VIKOR \\
\hline $\begin{array}{l}\text { Günay vd. } \\
\text { (2018) }\end{array}$ & $\begin{array}{l}\text { Likidite, finansal yap1, devir hızı ve karlılık } \\
\text { oranları }\end{array}$ & Gri İlişkisel Analiz \\
\hline $\begin{array}{l}\text { Karaoğlan ve } \\
\text { Şahin (2018) }\end{array}$ & $\begin{array}{l}\text { Likidite, finansal yap1, devir hızı ve karlılık } \\
\text { oranları }\end{array}$ & $\begin{array}{c}\text { TOPSIS, Gri } \\
\text { İlişkisel Analiz, } \\
\text { VIKOR, MOORA }\end{array}$ \\
\hline $\begin{array}{l}\text { Konak vd. } \\
(2018)\end{array}$ & $\begin{array}{l}\text { Likidite, finansal yap1, devir hızı ve karlılık } \\
\text { oranları }\end{array}$ & TOPSIS MOORA \\
\hline $\begin{array}{l}\text { Tütüncü ve } \\
\text { Uysal (2018) }\end{array}$ & $\begin{array}{l}\text { Cari oran, asit-test oran, alacak devir hızı oranı, } \\
\text { varlık devir hızı oranı, kaldıraç oranı, aktif } \\
\text { karlılığı, özsermaye karlılığı ve satışların karlığı }\end{array}$ & ROE ve TOPSIS \\
\hline $\begin{array}{l}\text { Uludağ ve } \\
\text { Ece (2018) }\end{array}$ & $\begin{array}{l}\text { Sermaye yeterliliği, aktif kalitesi, büyüklük, } \\
\text { likidite, karlılık, büyüme oranı ve risk ana } \\
\text { kriterleri ve bu kriterlere ilişkin alt kriterler }\end{array}$ & TOPSIS \\
\hline $\begin{array}{l}\text { Yildirim vd. } \\
(2018)\end{array}$ & $\begin{array}{l}\text { Likidite oranları, devir h1zı oranlar1, finansal } \\
\text { yap1 oranlar1, karlılık oranları, } \mathrm{F} / \mathrm{K} \text { oranı ve } \\
\text { PD/DD oranı }\end{array}$ & Entropi ve TOPSIS \\
\hline
\end{tabular}




\section{ENTROPI}

Entropi kavramı 1865 yılında Clausius tarafindan, termodinamikte düzensizlik ve dağınıklığın bir ölçütü olarak literatüre giren bir kavramdır. Termodinamiğin ikinci yasası olan Entropi kavramı, evrende kendi haline ve doğal şartlara bırakılan tüm sistemlerin zaman içerisinde dağınıklığa ve düzensizliğe uğrayıp bozulacağı anlamı taşımaktadır. Bu kavram Shannon (1948) tarafindan kesikli olasılık dağılımı ile açıklanan belirsizliğin ölçüsü olarak farklı bir şekilde enformasyon teorisi açısından tanımlanmıştır (Zhang vd., 2011: 444).

Birden çok kriteri içerisinde bulunduran karar verme problemlerinde, kriter ağırlıklarının hesaplanması oldukça önemli bir konudur. Entropi yöntemi literatürde yer alan ağırlık hesaplama yöntemlerinden objektif olanlar kategorisinde değerlendirilmektedir. Entropi yönteminde karar probleminde yer alan kriterlere ilişkin ağırlıklarının hesaplanması için, karar matrisindeki veriler kullanılmaktadır. Başka herhangi bir subjektif değerlendirmeye ihtiyaç duyulmaması nedeniyle yöntemin uygulanabilirliği oldukça kolaydır. Entropi yöntemi beş aşamadan oluşan bir uygulama sürecine sahiptir (Erol ve Ferrell, 2009: 1196-1197; Wang ve Lee, 2009: 8982; Özdağoğlu vd..2017: 346-347)

1. Aşama: Karar Matrisinin Oluşturulması: Yöntemin ilk aşamasında $x_{i j}$ değerlerinden oluşan ve $D$ ile simgelenen karar matrisi Eşitlik (1)'de gösterilen şekilde oluşturulur.

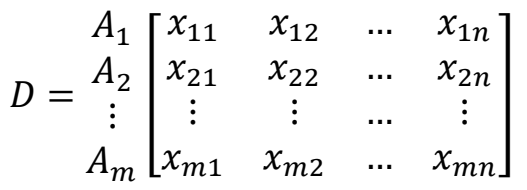

Eşitlik (1)'de yer alan $x_{i j}$ değerleri, $j$. değerlendirme kriterine göre i. alternatifin aldığı değerleri göstermektedir. ( $i$, karar alternatifi sayısı $i=1,2, \ldots, m ; j$ ise değerlendirme kriteri sayısı $j=1,2, \ldots, n$ sayıs1).

2. Aşama: Karar Matrisinin Normalizasyonu: Karar problemlerinde yer alan farklı birimlere sahip kriterlere ilişkin değerler, normalizasyon işlemiyle [0,1] 


\section{E. AYÇIN}

aralığında değer alacak şekilde standart bir hale getirilmelidir. Normalizasyon işlemi Eşitlik (2)'den yararlanılarak gerçekleştirilir.

$$
p_{i j}=\frac{x_{i j}}{\sum_{i=1}^{m} x_{i j}} \forall i, j
$$

Eşitlik (2)'de yer alan $p_{i j}$ : değerleri, $j$. değerlendirme kriterine göre $i$. alternatifin aldığı normalize değeri göstermektedir.

3. Aşama: Kriterlere Iliş̧kin Entropi Değerlerinin Bulunması: Bu aşamada her bir değerlendirme kriterinin Entropi değerleri $\left(e_{j}\right)$, Eşitlik (3)'te gösterilen şekilde hesaplanir.

$$
e_{i j}=-k \cdot \sum_{j=1}^{n} p_{i j} \cdot \ln \left(p_{i j}\right) \quad i=1,2, \ldots, m \text { ve } j=1,2, \ldots, n
$$

Eşitlik (3)' de yer alan $k$ değeri $k=(\ln (m))^{-1}$ olarak tanımlanan sabit bir katsayıdır ve $0 \leq e_{j} \leq 1$ olacak şekilde değer alır. $e_{j}$ değeri, $j$. kriterin belirsizlik ölçüsü ya da diğer bir ifadeyle Entropi değeri olarak tanımlanır.

4. Aşama: Farklılaşma Derecelerinin Bulunması: Bu aşamada, bir önceki aşamada hesaplanan Entropi değerleri kullanılarak, farklılaşma dereceleri (degree of diversification) olan $d_{j}$ değerleri her bir kriter için Eşitlik (4)'de gösterilen şekilde hesaplanır.

$$
d_{j}=1-e_{j} \quad j=1,2, \ldots, n
$$

5. Aşama: Entropi Kriter Ă̆ırlıklarının Hesaplanması: Yöntemin son aşamasında her bir kriterin farklılaşma derecesini, toplam farklılaştırma derecesine oranlayarak kriterlerin ağırlık değerleri $\left(\mathrm{w}_{\mathrm{j}}\right)$ Eşitlik (5)'de gösterilen şekilde hesaplanır

$$
w_{j}=\frac{d_{j}}{\sum_{j=1}^{n} d_{j}}
$$

Entropi yönteminde kriterlere ilişkin Entropi değerleri hesaplanırken, doğal logaritma fonksiyonu kullanılmaktadır. Karar problemine ilişkin karar matrisinde 
sıfır ya da negatif değerler olması durumunda, logaritmik hesaplamaların yapılmasında sıkıntı yaşanmaktadır. Bu yüzden negatif veriler için düzeltmeler yapılmalıdır. Bu çalışmada Zhang vd. (2014) tarafından geliştirilen Z-skoru standartlaştırma dönüşümü kullanılan entropi (improved entropy) yöntemi ile negatif veriler için düzeltmeler yapılmıştır. Bu yöntemde önce karar matrisinde yer alan değerler Eşitlik (6)'dan yararlanılarak Z-skoru standartlaştırması ile dönüştürülür.

$$
z_{i j}=\frac{x_{i j}-\bar{X}_{j}}{\sigma_{j}}
$$

Daha sonra Eşitlik (7)'de gösterilen dönüşüm yapılarak karar matrisindeki veriler pozitif hale getirilmiş olur.

$$
z_{i j}^{\prime}=z_{i j}+A ; \quad A>\left|\min z_{i j}\right|
$$

\section{GRİ İLISSKİSEL ANALİZ}

Gri İlişkisel Analiz (GİA), Denk tarafından literatüre kazandırılan Gri sistem teorisi (Denk,1989) temelinde geliştirilmiş olan çok kriterli karar verme problemlerinin çözümünde kullanılabilen önemli bir sınıflama, derecelendirme ve karar verme yöntemidir. GİA, nicel ve dilsel değişkenlerin kullanıldığı nitel verileri içinde bulunduran ÇKKV problemlerinin çözümünde hem tek başına hem de diğer yöntemlerle bütünleşik bir şekilde kullanılabilir.

Az sayıda veriye ihtiyaç duyması, belirsizlik durumunda verilerle etkin sonuçlar üretebilmesi, gri ilişki katsayılarının hesaplanmasının kolay olması ve veri setinin herhangi bir dağılıma uygun olma zorunluluğunun olmaması yöntemin avantaj1ı yönleridir. Bir olasılık dağılımından bağımsız olan GİA, küçük örnek hacimleri ile yapılan çalışmalarda diğer istatistiksel analiz tekniklerine göre daha iyi sonuçlar ortaya koyabilmektedir (Kung vd., 2006:156). Gri İlişkisel Analiz yönteminin uygulama süreci altı aşamadan oluşmaktadır (Hsu ve Wen, 2000; Wu, 2002; Zhai vd., 2009; Yıldırım ve Önder, 2015): 


\section{E. AYÇIN}

1. Aşama: Verilerin Hazırlanması ve Karar Matrisinin Oluşturulması: Yöntemin ilk aşamasında karar probleminde yer alan, karşılaştırma yapılacak $m$ adet faktör serisi Eşitlik (8)'de gösterilen şekilde belirlenir.

$$
x_{i}=\left(x_{i}(j), \ldots,{ }_{i} x_{i}(n)\right) i=1,2, \ldots, m ; j=1,2, \ldots, n
$$

Eşitlik (8)'de yer alan $x_{i}$ 'ler karar alternatiflerini; $x_{i}(j)$ değerleri ise $i$. karar alternatifinin $j$. kriter için aldığ 1 değeri göstermektedir. $m$ adet serinin oluşturulmasıyla elde edilen karar matrisi “ $X$ ”, Eşitlik (9)'da gösterilmiştir.

$$
X=\left[\begin{array}{cccc}
x_{1}(1) & x_{1}(2) & \cdots & x_{1}(n) \\
x_{2}(1) & x_{2}(2) & \cdots & x_{2}(n) \\
\vdots & \vdots & \cdots & \vdots \\
\vdots & \vdots & \cdots & \vdots \\
\vdots & \vdots & \ddots & \vdots \\
x_{m}(1) & x_{m}(2) & \cdots & x_{m}(n)
\end{array}\right]
$$

2. Aşama: Referans Serisinin ve Karşılaştırma Matrisinin Oluşturulması: $\mathrm{Bu}$ aşamada öncelikle, karar probleminde yer alan faktörleri kıyaslamak amacıyla Eşitlik (10)'da gösterilen şekilde referans seri oluşturulmalıdır.

$$
x_{0}=\left(x_{0}(j)\right) j=1,2, \ldots, n
$$

Eşitlik (10)'da yer alan $x_{0}(j)$ değeri, $j$. kriterin bir sonraki aşamada elde edilecek normalize değerler arasındaki, en iyi değerini göstermektedir.

Referans seri, bir karar alternatifi için kriterler göz önüne alındığında, her bir kriter için ideal değerleri belirlenerek oluşturulabilir. Referans serinin belirlenmesindeki diğer yol ise, karar alternatiflerinin her bir kriter için aldıkları değerlerin en iyilerini kullanmaktır. Fayda yönlü kriterlerde, o kriter için veri setinde yer alan en büyük değerin referans seriye alınması gerekirken; maliyet yönlü kriterlerde ise en küçük değer referans seriye alınarak, referans seri oluşturulur. Referans seri oluşturulduktan sonra, ilk aşamada oluşturulan karar matrisinin ilk satırına eklenerek, karşılaştırma matrisi elde edilir. 
3. Aşama: Normalizasyon İşlemi ve Normalize Matrisinin Elde Edilmesi: Normalizasyon işlemi fayda, maliyet ve optimal (en uygun) durumlarına göre üç farklı şekilde gerçekleştirilebilir. Fayda durumundaki kriterler dikkate alındığında, kriterin alacağı değerin en büyük olması amaca uygun olmaktadır. Fayda durumuna ilişkin normalizasyon işlemi Eşitlik (11) kullanılarak gerçekleştirilir.

$$
x_{i}^{*}=\frac{x_{i}(j)-\min _{j} x_{i}(j)}{\max _{j} x_{i}(j)-\min _{j} x_{i}(j)}
$$

Maliyet durumundaki kriterler dikkate alındığında, kriterin alacağı değerin en küçük olması amaca uygun olmaktadır. Maliyet durumuna ilişkin normalizasyon işlemi Eşitlik (12) kullanılarak gerçekleştirilir.

$$
x_{i}^{*}=\frac{\max _{j} x_{i}(j)-x_{i}(j)}{\max _{j} x_{i}(j)-\min _{j} x_{i}(j)}
$$

Optimal durumun dikkate alınması gereken kriterler mevcutsa, kriterin bu optimal değeri alması amaca uygun olmaktadır. Optimal duruma ilişkin normalizasyon işlemi Eşitlik (13) kullanılarak gerçekleştirilir.

$$
x_{i}^{*}=\frac{x_{i}(j)-x_{0 b}(j)}{\max _{j} x_{i}(j)-x_{0 b}(j)}
$$

Eşitlik (13)'de yer alan $x_{0 b}(j)$ değeri, belirlenen optimal değer olup $j$. kriterin hedef değerini göstermektedir. Optimal değer $\min _{j} x_{i}(j) \leq x_{0 b} \leq \max _{j} x_{i}(j)$ aralığında değer alabilir. Normalize edilmiş karar matrisi ise Eşitlik (14)'de gösterilmiştir.

$$
X^{*}=\left[\begin{array}{cccc}
x_{1}{ }^{*}(1) & x_{1}{ }^{*}(2) & \cdots & x_{1}{ }^{*}(n) \\
x_{2}{ }^{*}(1) & x_{2}{ }^{*}(2) & \cdots & x_{2}{ }^{*}(n) \\
\vdots & \vdots & \cdots & \vdots \\
\vdots & \vdots & \cdots & \vdots \\
\vdots & \vdots & \ddots & \vdots \\
x_{m}{ }^{*}(1) & x_{m}{ }^{*}(2) & \cdots & x_{m}{ }^{*}(n)
\end{array}\right]
$$




\section{E. AYÇIN}

4. Aşama: Fark Matrisinin Oluşturulması: $\mathrm{Bu}$ aşamada referans serinin normalize değerleri ile normalize karar matrisinin değerleri arasındaki farkın değeri Eşitlik (15)'de gösterilen şekilde hesaplanır.

$$
\Delta_{0 i}=x_{0}{ }^{*}(j)-x_{i}{ }^{*}(j)
$$

Eşitlik (15)'den yararlanılarak hesaplanan değerler ile Eşitlik (16)'da gösterilen fark matrisi elde edilir.

$$
\Delta_{0 i}=\left[\begin{array}{cccc}
\Delta_{01}(1) & \Delta_{01}(2) & \cdots & \Delta_{01}(n) \\
\Delta_{02}(1) & \Delta_{02}(2) & \cdots & \Delta_{02}(n) \\
\vdots & \vdots & \cdots & \vdots \\
\vdots & \vdots & \cdots & \vdots \\
\vdots & \vdots & \ddots & \vdots \\
\Delta_{0 m}(1) & \Delta_{0 m}(2) & \cdots & \Delta_{0 m}(n)
\end{array}\right]
$$

5. Aşama: Gri İlişkisel Katsayı Matrisinin Oluşturulması: Gri ilişkisel katsayı matrisinde yer alan elemanlar Eşitlik (17), (18) ve (19) kullanılarak hesaplanmaktadır.

$$
\begin{aligned}
\gamma_{0 i}(j) & =\frac{\Delta_{\min }+\zeta \cdot \Delta_{\max }}{\Delta_{0 i}(j)+\zeta \cdot \Delta_{\max }} \\
\Delta_{\max } & =\max _{i} \max _{j} \Delta_{0 i}(j) \\
\Delta_{\min } & =\min _{i} \min _{j} \Delta_{0 i}(j)
\end{aligned}
$$

Eşitlik (17)'de yer alan ve $[0,1]$ aralığında değer alabilen " $\zeta$ "parametresi, “ayırıcı katsayı" veya "zıtlık kontrol katsayısı" olarak adlandırılır. Bu katsayı $\Delta_{0 i}$ ile $\Delta_{\max }$ arasındaki farkı düzenlemek için kullanılmaktadır. “ $\zeta$ "parametresinin aldığı değer 1'e doğru yaklaştıkça ayırıcı özellik (zıtlık) artacaktır. Bu değer 0'a doğru yaklaştıkça ise zıtlığın ortadan kalkacağı bir durum ortaya çıkacaktır. Veri setinde yer alan değerler arasındaki farkların çok fazla olması durumunda, zıtlığ azaltmak amacıyla " $\zeta$ "parametresi olarak sıfıra yakın değerler seçilir. Literatürdeki çalışmalar incelendiğinde, birçoğunda bu katsayının 0,5 olarak kullanıldığı görülmüştür. 
6. Aşama: Gri Iliş̧kisel Derecelerin Belirlenmesi: Gri ilişkisel derece, gri bir sistemde yer alan $x_{i}^{*}$ serisi ile referans seri $\left(x_{0}{ }^{*}\right)$ arasındaki geometrik benzerliğin bir ölçüsü olarak, bu serilerin karşılaştırılmasına olanak tanımaktadır. Gri ilişkisel dereceler $\left(\Gamma_{0 i}\right)$, karar probleminde yer alan kriterlerin önem düzeylerine göre farklı şekillerde hesaplanır. Eğer karar problemindeki kriterler eşit önem düzeyinde değerlendiriliyorsa, gri ilişkisel derece Eşitlik (20) yardımıyla hesaplanır.

$$
\Gamma_{0 i}=\frac{1}{n} \sum_{j=1}^{n} \gamma_{0 i}(j)
$$

Eğer karar problemindeki kriterler farklı önem düzeyinde değerlendiriliyorsa, kriter ağırlıklarının da formüle eklenmesiyle gri ilişkisel derece Eşitlik (21) yardımıyla hesaplanır.

$$
\Gamma_{0 i}=\sum_{j=1}^{n}\left[w_{i}(j) \cdot \gamma_{0 i}(j)\right]
$$

Eşitlik (21)'de yer alan $w_{i}(j)$ değeri $j$. kriterin, kriter ağırlığını göstermektedir. Kriterlere ilişkin ağırlık değerleri $\left(w_{j}\right)$ toplamları 1 olmalıdır. Gri ilişkisel derecelerin hesaplanması ile yöntemin son aşaması tamamlanmış olur. Gri ilişkisel dereceler, büyükten küçüğe doğru sıralanarak karar alternatiflerine ilişkin sıralama elde edilir. En yüksek gri ilişkisel derece değerine sahip karar alternatifi, en iyi alternatif olarak belirlenir (Lin ve Lin, 2005: 11).

\section{UYGULAMA}

Çalışmada BIST Menkul Kıymet Yatırım Ortaklıkları Endeksinde (XYORT) yer alan işletmelerin finansal performanslarının değerlendirilmesi amaçlanmıştır. $\mathrm{Bu}$ endekste yer alan işletmeler Tablo 2'de gösterilmiştir. 


\section{E. AYÇİN}

Tablo 2. Menkul Kıymet Yatırım Ortaklıkları Endeksinde yer Alan İşletmeler

\begin{tabular}{|c|c|}
\hline BIST Kodu & İşletme Adı \\
\hline ATLAS & Atlas Menkul Kıymetler Yatırım Ortaklığı A.Ş. \\
\hline EUKYO & Euro Kapital Yatırım Ortaklığı A.Ş. \\
\hline EUYO & Euro Menkul Kıymet Yatırım Ortaklığ1 A.Ş. \\
\hline ETYAT & Euro Trend Yatırım Ortaklığı A.Ş. \\
\hline GRNYO & Garanti Yatırım Ortaklığı A.Ş. \\
\hline ISYAT & İş Yatırım Ortaklığı A.Ş. \\
\hline MTRYO & Metro Yatırım Ortaklığı A.Ş. \\
\hline OYAYO & Oyak Yatırım Ortaklığı A.Ş. \\
\hline VKFYO & Vakıf Menkul Kıymet Yatırım Ortaklığı A.Ş \\
\hline
\end{tabular}

Finansal performansın değerlendirilmesi çalışma kapsamında yer alan kriterler, hem literatür taraması hem de sektördeki yatırım uzmanlarının görüşleri dikkate alınarak belirlenmiştir. Çalışmada yer alacak kriterler, fiyat/kazanç oranı, piyasa değeri/defter değeri oranı, Beta endeksi, temettü verimliliği, öz sermaye karlılık oranı ve piyasa katma değeri olarak belirlenmiştir. Belirlenen kriterlere ilişkin tanımlamalar Tablo 3 'te gösterilmiştir.

Tablo 3. Değerlendirme Kriterleri ve Tanımlamalar

\begin{tabular}{|c|c|}
\hline Kriter & Tanımlama \\
\hline F/K Oranı & $\begin{array}{l}\text { İşletme hisselerinin fiyatının, hisse başına düşen kara oranlanması ile } \\
\text { hesaplanır. F/K oranının sektör ortalaması altında kalması olumlu bir } \\
\text { gösterge olarak kabul edilmiştir. }\end{array}$ \\
\hline PD/DD Oranı & $\begin{array}{l}\text { İşletmenin piyasa değeri ile defter değerinin oranlanması ile } \\
\text { hesaplanır. Bu oranın sektör ortalamasına göre düşük olması olumlu } \\
\text { bir göstergedir. PD/DD'nin 1'den küçük olması hissenin } \\
\text { özvarlıklarının altında, 1'e eşit olması özvarlıklarına eşit, 1'den } \\
\text { büyük olması özvarlıklarının üzerinde değere satıldığını gösterir. }\end{array}$ \\
\hline \multirow{4}{*}{ Beta Endeksi } & $\begin{array}{l}\text { Hisse senedinin Beta katsayısı, menkul kıymetlere ait riskin nicel bir } \\
\text { ölçüsüdür. }\end{array}$ \\
\hline & $\checkmark \quad \beta=1$ ise hissenin hareketi endeksle aynı (ortalama risk) \\
\hline & $\checkmark \quad \beta<1$ ise hissenin hareketi endeksten daha yavaş (az riskli) \\
\hline & $\checkmark \quad B>1$ ise hissenin hareketi endeksten daha hizlı (daha riskli) \\
\hline $\begin{array}{l}\text { Temettü } \\
\text { Verimliliği }\end{array}$ & $\begin{array}{l}\text { İşletmenin hisse senedi başına ödediği temettü miktarı ile hisse senedi } \\
\text { fiyatının oranlanması ile bulunur. Bu oranın yüksek olması olumlu bir } \\
\text { göstergedir. }\end{array}$ \\
\hline $\begin{array}{c}\text { Özsermaye } \\
\text { Karlılık } \\
\text { Oranı (ROE) } \\
\end{array}$ & $\begin{array}{l}\text { Özsermaye miktarının net kara oranlanması ile hesaplanır. Bu oranın } \\
\text { yüksek olması olumlu bir göstergedir. }\end{array}$ \\
\hline $\begin{array}{l}\text { Piyasa Katma } \\
\text { Değeri } \\
\text { (MVA) } \\
\end{array}$ & $\begin{array}{l}\text { Piyasa değeri-Yatırılan sermaye formülü ile hesaplanır. Bu değerin } \\
\text { yüksek olması olumlu bir göstergedir. }\end{array}$ \\
\hline
\end{tabular}


BIST XYORT endeksinde yer alan dokuz işletmeden sekizine ilişkin 2018 y1lı Haziran dönemindeki en güncel finansal tabloları dikkate alınarak, her kriter için ilgili değerler hesaplanmış ve karar matrisi Tablo 4'te gösterilmiştir (Vakıf Menkul Kıymet Yatırım Ortaklı̆̆ına ilişkin temettü verimliliği ve $F / K$ oranı, işletmenin olumsuz finansal göstergelerinden dolayı hesaplanamadiğından, bu işletme analiz dışında bırakılmıştır).

Tablo 4. Karar Matrisi

\begin{tabular}{|c|c|c|c|c|c|c|}
\hline İşletme/Kriter & F/K & PD/DD & $\begin{array}{c}\text { Beta } \\
\text { Endeksi }\end{array}$ & $\begin{array}{c}\text { Temettü } \\
\text { Verimliliği }\end{array}$ & $\begin{array}{c}\text { Ozsermaye } \\
\text { Karlılığl } \\
\text { (ROE) }\end{array}$ & $\begin{array}{c}\text { Piyasa } \\
\text { Katma } \\
\text { Değeri } \\
\text { (MVA) }\end{array}$ \\
\hline ATLAS & 4,67 & 0,55 & 0,85 & 6,34 & 0,0863 & -4.200 .000 \\
\hline EUKYO & 8,95 & 0,54 & 0,43 & 2,88 & 0,0175 & -6.000 .000 \\
\hline EUYO & 17,08 & 0,51 & 0,68 & 3,03 & 0,0121 & -8.200 .000 \\
\hline ETYAT & 14,09 & 0,55 & 0,58 & 2,94 & 0,0146 & -7.800 .000 \\
\hline GRNYO & 15,46 & 0,58 & 0,74 & 2,19 & 0,0053 & -12.480 .000 \\
\hline ISYAT & 6,52 & 0,59 & 0,24 & 23,38 & 0,0377 & -35.331 .842 \\
\hline MTRYO & 16,92 & 0,49 & 0,98 & 3,60 & 0,0025 & 1.050 .000 \\
\hline OYAYO & 13,11 & 1,24 & 0,51 & 1,62 & 0,0578 & -600.000 \\
\hline
\end{tabular}

Karar matrisi oluşturulduktan sonra, uygulamanın ilk basamağını oluşturan Entropi yöntemiyle kriter ağırlıkları belirlenecektir. Tablo 4'te gösterilen karar matrisinde yer alan piyasa katma değeri kriterinde negatif değerler bulunması nedeniyle, Eşitlik (6) ve (7)'den yararlanılarak veriler pozitif hale dönüştürülmelidir. Elde edilen düzenlenmiş karar matrisi Tablo 5'te gösterilmektedir.

Tablo 5. Düzenlenmiş Karar Matrisi

\begin{tabular}{|c|c|c|c|c|c|c|}
\hline İșletme/Kriter & F/K & PD/DD & $\begin{array}{c}\text { Beta } \\
\text { Endeksi }\end{array}$ & $\begin{array}{c}\text { Temettü } \\
\text { Verimliliği }\end{array}$ & $\begin{array}{c}\text { Özsermaye } \\
\text { Karlılı̆ } \\
\text { (ROE) }\end{array}$ & $\begin{array}{c}\text { Piyasa } \\
\text { Katma } \\
\text { Değeri } \\
\text { (MVA) }\end{array}$ \\
\hline ATLAS & 4,67 & 0,55 & 0,85 & 6,34 & 0,0863 & 2,738 \\
\hline EUKYO & 8,95 & 0,54 & 0,43 & 2,88 & 0,0175 & 2,580 \\
\hline EUYO & 17,08 & 0,51 & 0,68 & 3,03 & 0,0121 & 2,387 \\
\hline ETYAT & 14,09 & 0,55 & 0,58 & 2,94 & 0,0146 & 2,422 \\
\hline GRNYO & 15,46 & 0,58 & 0,74 & 2,19 & 0,0053 & 2,012 \\
\hline ISYAT & 6,52 & 0,59 & 0,24 & 23,38 & 0,0377 & 0,009 \\
\hline MTRYO & 16,92 & 0,49 & 0,98 & 3,60 & 0,0025 & 3,198 \\
\hline OYAYO & 13,11 & 1,24 & 0,51 & 1,62 & 0,0578 & 3,053 \\
\hline
\end{tabular}




\section{E. AYÇİN}

Karar matrisindeki değerler düzenlendikten sonra, Eşitlik (2)'den yararlanılarak Tablo 5'te gösterilen karar matrisi normalize edilir. Normalize edilen karar matrisi Tablo 6'da gösterilmektedir.

Tablo 6. Normalize Karar Matrisi

\begin{tabular}{|c|c|c|c|c|c|c|}
\hline \multirow{2}{*}{ İşletme/Kriter } & F/K & PD/DD & $\begin{array}{c}\text { Beta } \\
\text { Endeksi }\end{array}$ & $\begin{array}{c}\text { Temettï } \\
\text { Verimliliği }\end{array}$ & $\begin{array}{c}\text { Ozsermaye } \\
\text { Karlılığl } \\
\text { (ROE) }\end{array}$ & $\begin{array}{c}\text { Piyasa } \\
\text { Katma } \\
\text { Değeri } \\
\text { (MVA) }\end{array}$ \\
\cline { 2 - 7 } & 0,048 & 0,109 & 0,170 & 0,138 & 0,369 & 0,149 \\
\hline EUKYS & 0,092 & 0,107 & 0,086 & 0,063 & 0,075 & 0,140 \\
\hline EUYO & 0,176 & 0,101 & 0,136 & 0,066 & 0,052 & 0,130 \\
\hline ETYAT & 0,146 & 0,109 & 0,116 & 0,064 & 0,062 & 0,132 \\
\hline GRNYO & 0,160 & 0,115 & 0,148 & 0,048 & 0,023 & 0,109 \\
\hline ISYAT & 0,067 & 0,117 & 0,048 & 0,508 & 0,161 & 0,000 \\
\hline MTRYO & 0,175 & 0,097 & 0,196 & 0,078 & 0,011 & 0,174 \\
\hline OYAYO & 0,135 & 0,246 & 0,102 & 0,035 & 0,247 & 0,166 \\
\hline
\end{tabular}

Bir sonraki aşamada Eşitlik (3)'de gösterildiği üzere, Tablo 6'da gösterilen normalize edilmiş değerler $\left(p_{i j}\right)$ ile bu değerlerin logaritma değerleri $\left(\ln \left(p_{i j}\right)\right)$ birbirleriyle çarpılıp, toplanmalıdır. Eşitlik (3)'de yer alan bir diğer değer olan $k$ değeri ise karar alternatifi sayısının logaritması alınarak hesaplanmaktadır. Uygulamada sekiz tane işletme yer aldığından bu değer, $k=(\ln (m))^{-1}$ formülünden yararlanılarak $k=(\ln (8))^{-1}=0,4839$ olarak hesaplanır. Elde edilen Entropi değerleri $\left(\boldsymbol{e}_{\boldsymbol{j}}\right)$ Tablo 7'de gösterilmiştir.

Tablo 7. Entropi Değerlerinin Elde Edilmesi

\begin{tabular}{|c|c|c|c|c|c|c|}
\hline İşletme/Kriter & F/K & PD/DD & $\begin{array}{c}\text { Beta } \\
\text { Endeksi }\end{array}$ & $\begin{array}{c}\text { Temettü } \\
\text { Verimliliği }\end{array}$ & $\begin{array}{c}\text { Özsermaye } \\
\text { Karlılığı } \\
\text { (ROE) }\end{array}$ & $\begin{array}{l}\text { Piyasa } \\
\text { Katma } \\
\text { Değeri } \\
\text { (MVA) }\end{array}$ \\
\hline ATLAS & $-0,146$ & $-0,241$ & $-0,301$ & $-0,273$ & $-0,368$ & $-0,283$ \\
\hline EUKYO & $-0,220$ & $-0,239$ & $-0,211$ & $-0,174$ & $-0,194$ & $-0,275$ \\
\hline EUYO & $-0,306$ & $-0,232$ & $-0,271$ & $-0,179$ & $-0,153$ & $-0,265$ \\
\hline ETYAT & $-0,281$ & $-0,241$ & $-0,250$ & $-0,176$ & $-0,173$ & $-0,267$ \\
\hline GRNYO & $-0,293$ & $-0,249$ & $-0,282$ & $-0,145$ & $-0,086$ & $-0,242$ \\
\hline ISYAT & $-0,182$ & $-0,251$ & $-0,146$ & $-0,344$ & $-0,294$ & $-0,004$ \\
\hline MTRYO & $-0,305$ & $-0,226$ & $-0,319$ & $-0,199$ & $-0,049$ & $-0,304$ \\
\hline OYAYO & $-0,271$ & $-0,345$ & $-0,233$ & $-0,118$ & $-0,345$ & $-0,298$ \\
\hline Toplam & $-2,003$ & $-2,024$ & $-2,012$ & $-1,608$ & $-1,662$ & $-1,939$ \\
\hline \multicolumn{6}{|c|}{$1 / \ln (8)=0,4839$} & \\
\hline $\boldsymbol{e}_{j}$ & 9634 & 0,9734 & 0,9677 & $\mathbf{0 , 7 7 3 3}$ & 0,7995 & $\mathbf{0 , 9 3 2 3}$ \\
\hline
\end{tabular}


Entropi değerleri elde edildikten sonra Eşitlik (4)'ten yararlanılarak farklılaşma dereceleri $\left(\boldsymbol{d}_{\boldsymbol{j}}\right)$ hesaplanır. Son olarak Eşitlik (5)'ten yararlanılarak her bir kriterin farklılaşma derecesi, toplam farklılaştırma derecesine oranlanarak kriter ağırlıkları Tablo 8'de gösterilen şekilde elde edilir.

Tablo 8. Entropi Yöntemiyle Hesaplanan Kriter Ağırlıkları

\begin{tabular}{|c|c|c|c|c|c|c|}
\hline Kriter & F/K & PD/DD & $\begin{array}{c}\text { Beta } \\
\text { Endeksi }\end{array}$ & $\begin{array}{c}\text { Temettü } \\
\text { Verimliliği }\end{array}$ & $\begin{array}{c}\text { Ozsermaye } \\
\text { Karlı̆ı̆ı } \\
\text { (ROE) }\end{array}$ & $\begin{array}{c}\text { Piyasa } \\
\text { Katma } \\
\text { Değeri } \\
\text { (MVA) }\end{array}$ \\
\hline $\boldsymbol{d}_{\boldsymbol{j}}$ & 0,0366 & 0,0266 & 0,0323 & 0,2267 & 0,2005 & 0,0677 \\
\hline $\boldsymbol{w}_{\boldsymbol{j}}$ & $\mathbf{0 , 0 6 2 0}$ & $\mathbf{0 , 0 4 5 1}$ & $\mathbf{0 , 0 5 4 8}$ & $\mathbf{0 , 3 8 4 0}$ & $\mathbf{0 , 3 3 9 6}$ & $\mathbf{0 , 1 1 4 6}$ \\
\hline
\end{tabular}

Entropi yöntemiyle kriter ağırlıkları hesaplandıktan sonra uygulamanın ikinci aşaması olan Gri İlişkisel Analiz yöntemiyle, işletmelerin finansal performansları değerlendirilecektir. Yöntemin ilk aşamasında Tablo 5'teki düzenlenmiş karar matrisinde yer alan verilerden yararlanılacaktır. $\mathrm{Bu}$ matrise referans seri eklenip, kriterlerin yönleri de belirlendikten sonra Gri İlişkisel Analiz için Tablo 9'da gösterilen karar matrisi elde edilecektir. Uygulamada, karar matrisinde yer alan her bir kriterin en iyi değerleri dikkate alınarak referans seri belirlenmiştir. Kriter yönleri belirlenirken, Tablo 3'te gösterilmiş olan kriter tanımlamaları ve değerlendirmeler dikkate alınmıştır.

Tablo 9. Referans Serinin Karar Matrisine Eklenmesi

\begin{tabular}{|c|c|c|c|c|c|c|}
\hline İşletme/Kriter & F/K & PD/DD & $\begin{array}{c}\text { Beta } \\
\text { Endeksi }\end{array}$ & $\begin{array}{c}\text { Temettü } \\
\text { Verimliliği }\end{array}$ & $\begin{array}{c}\text { Ozzsermaye } \\
\text { Karlıı̆g } \\
\text { (ROE) }\end{array}$ & $\begin{array}{c}\text { Piyasa } \\
\text { Katma } \\
\text { Değeri } \\
\text { (MVA) }\end{array}$ \\
\hline Kriter Yönleri & min & min & min & maks & maks & maks \\
\hline Referans Seri & $\mathbf{4 , 6 7}$ & $\mathbf{0 , 4 9}$ & $\mathbf{0 , 2 4}$ & $\mathbf{2 3 , 3 8}$ & $\mathbf{0 , 0 8 6 3}$ & $\mathbf{3 , 1 9 8}$ \\
\hline ATLAS & 4,67 & 0,55 & 0,85 & 6,34 & 0,0863 & 2,738 \\
\hline EUKYO & 8,95 & 0,54 & 0,43 & 2,88 & 0,0175 & 2,580 \\
\hline EUYO & 17,08 & 0,51 & 0,68 & 3,03 & 0,0121 & 2,387 \\
\hline ETYAT & 14,09 & 0,55 & 0,58 & 2,94 & 0,0146 & 2,422 \\
\hline GRNYO & 15,46 & 0,58 & 0,74 & 2,19 & 0,0053 & 2,012 \\
\hline ISYAT & 6,52 & 0,59 & 0,24 & 23,38 & 0,0377 & 0,009 \\
\hline MTRYO & 16,92 & 0,49 & 0,98 & 3,6 & 0,0025 & 3,198 \\
\hline OYAYO & 13,11 & 1,24 & 0,51 & 1,62 & 0,0578 & 3,053 \\
\hline
\end{tabular}




\section{E. AYÇİN}

Bir sonraki aşamada, maksimizasyon yönlü kriterler için Eşitlik (11), minimizasyon yönlü kriterler için ise Eşitlik (12)'den yararlanılarak normalizasyon işlemi gerçekleştirilir. Normalize edilmiş karar matrisi Tablo 10'da gösterilmiştir.

Tablo 10. Normalize Edilmiş Karar Matrisi

\begin{tabular}{|c|c|c|c|c|c|c|}
\hline İşletme/Kriter & F/K & PD/DD & $\begin{array}{c}\text { Beta } \\
\text { Endeksi }\end{array}$ & $\begin{array}{c}\text { Temettü } \\
\text { Verimliliği }\end{array}$ & $\begin{array}{c}\text { Özsermaye } \\
\text { Karlılığı } \\
\text { (ROE) }\end{array}$ & MVA \\
\hline Kriter Yönleri & min & min & min & maks & maks & maks \\
\hline Referans Seri & 1 & 1 & 1 & 1 & 1 & 1 \\
\hline ATLAS & 1 & 0,9200 & 0,1757 & 0,2169 & 1 & 0,8557 \\
\hline EUKYO & 0,6551 & 0,9333 & 0,7432 & 0,0579 & 0,1790 & 0,8062 \\
\hline EUYO & 0 & 0,9733 & 0,4054 & 0,0648 & 0,1146 & 0,7458 \\
\hline ETYAT & 0,2409 & 0,9200 & 0,5405 & 0,0607 & 0,1444 & 0,7567 \\
\hline GRNYO & 0,1305 & 0,8800 & 0,3243 & 0,0262 & 0,0334 & 0,6281 \\
\hline ISYAT & 0,8509 & 0,8667 & 1 & 1 & 0,4200 & 0 \\
\hline MTRYO & 0,0129 & 1 & 0 & 0,0910 & 0 & 1 \\
\hline OYAYO & 0,3199 & 0 & 0,6351 & 0 & 0,6599 & 0,9546 \\
\hline
\end{tabular}

Normalize edilmiş karar matrisi elde edildikten sonra, referans serinin normalize değerleri ile matriste yer alan normalize değerler arasındaki farklar Eşitlik (15)'ten yararlanılarak hesaplanır. Hesaplanan değerlerden oluşan fark matrisi Tablo 11'de gösterilmiştir.

Tablo 11. Fark Matrisi

\begin{tabular}{|c|c|c|c|c|c|c|}
\hline İşletme/Kriter & F/K & PD/DD & $\begin{array}{c}\text { Beta } \\
\text { Endeksi }\end{array}$ & $\begin{array}{c}\text { Temettü } \\
\text { Verimliliği }\end{array}$ & $\begin{array}{c}\text { Özsermaye } \\
\text { Karlılı̆̆ } \\
\text { (ROE) }\end{array}$ & MVA \\
\hline ATLAS & 0 & 0,0800 & 0,8243 & 0,7831 & 0 & 0,1443 \\
\hline EUKYO & 0,3449 & 0,0667 & 0,2568 & 0,9421 & 0,8210 & 0,1938 \\
\hline EUYO & 1 & 0,0267 & 0,5946 & 0,9352 & 0,8854 & 0,2542 \\
\hline ETYAT & 0,7591 & 0,0800 & 0,4595 & 0,9393 & 0,8556 & 0,2433 \\
\hline GRNYO & 0,8695 & 0,1200 & 0,6757 & 0,9738 & 0,9666 & 0,3719 \\
\hline ISYAT & 0,1491 & 0,1333 & 0 & 0 & 0,5800 & 1 \\
\hline MTRYO & 0,9871 & 0 & 1 & 0,9090 & 1 & 0 \\
\hline OYAYO & 0,6801 & 1 & 0,3649 & 1 & 0,3401 & 0,0454 \\
\hline
\end{tabular}

Fark matrisi elde edildikten sonra, gri ilişkisel katsayı matrisi Eşitlik (17)(19)'dan yararlanılarak oluşturulacaktır. Eşitlik (17)'de yer alan $\zeta$ parametresi ise literatürdeki birçok çalışmada olduğu gibi 0,5 olarak dikkate alınmıştır. Hesaplamalar sonucu elde edilen Gri İlişkisel Katsayı Matrisi Tablo 12'de gösterilmiştir. 
Tablo 12. Gri İlişkisel Katsayı Matrisi

\begin{tabular}{|c|c|c|c|c|c|c|}
\hline İşletme/Kriter & F/K & PD/DD & $\begin{array}{c}\text { Beta } \\
\text { Endeksi }\end{array}$ & $\begin{array}{c}\text { Temettü } \\
\text { Verimliliği }\end{array}$ & $\begin{array}{c}\text { Özsermaye } \\
\text { Karlılığı } \\
\text { (ROE) }\end{array}$ & MVA \\
\hline ATLAS & 1 & 0,8621 & 0,3776 & 0,3897 & 1 & 0,7760 \\
\hline EUKYO & 0,5918 & 0,8824 & 0,6607 & 0,3467 & 0,3785 & 0,7207 \\
\hline EUYO & 0,3333 & 0,9494 & 0,4568 & 0,3484 & 0,3609 & 0,6629 \\
\hline ETYAT & 0,3971 & 0,8621 & 0,5211 & 0,3474 & 0,3688 & 0,6727 \\
\hline GRNYO & 0,3651 & 0,8065 & 0,4253 & 0,3393 & 0,3409 & 0,5735 \\
\hline ISYAT & 0,7703 & 0,7895 & 1 & 1 & 0,4630 & 0,3333 \\
\hline MTRYO & 0,3362 & 1 & 0,3333 & 0,3549 & 0,3333 & 1 \\
\hline OYAYO & 0,4237 & 0,3333 & 0,5781 & 0,3333 & 0,5952 & 0,9168 \\
\hline
\end{tabular}

Yöntemin son aşamasında Gri İlişkisel Dereceler hesaplanarak, işletmelerin finansal performanslarına göre sıralamaları yapılacaktır. Eşitlik (21)'den yararlanılarak, Tablo 8'de gösterilen Entropi yöntemiyle hesaplanan kriter ağırlıkları, Tablo 12'de gösterilen gri ilişkisel katsayılar ile çarpılıp toplanarak, her işletme için gri ilişkisel dereceler hesaplanmıştır. Hesaplanan değerler ve işletmelerin sıralaması Tablo 13'de gösterilmiştir.

Tablo 13. Gri İlişkisel Dereceler ve Sıralama

\begin{tabular}{|c|c|c|}
\hline İşletmeler & $\boldsymbol{\Gamma}_{\mathbf{0} \boldsymbol{i}}$ & Sıralama \\
\hline ATLAS & 0,6997 & 2 \\
\hline EUKYO & 0,4569 & 4 \\
\hline EUYO & 0,4208 & 7 \\
\hline ETYAT & 0,4278 & 6 \\
\hline GRNYO & 0,3940 & 8 \\
\hline ISYAT & 0,7175 & 1 \\
\hline MTRYO & 0,4482 & 5 \\
\hline OYAYO & 0,5081 & 3 \\
\hline
\end{tabular}

2018 y1lı haziran dönemi finansal tablo değerlerine göre menkul kıymet yatırım ortaklığı endeksinde yer alan işletmelerin finansal performanslarının değerlendirildiği uygulamanın sonuçları Tablo 13'de gösterilmiştir. İş Yatırım Ortaklığı finansal performansı en yüksek olan işletme olarak belirlenmiştir. İş Yatırım Ortaklığı'nı sırasıyla Atlas Menkul Kıymetler Yatırım Ortaklığı ve OYAK Yatırım Ortaklığı Takip etmiştir. 


\section{E. AYÇIN}

\section{SONUÇ}

$\mathrm{Bu}$ çalışmada finansal sistem içinde yer alan önemli kurumlardan olan menkul kıymet yatırım ortaklıklarının finansal performanslarının değerlendirilmesinde, ÇKKV yöntemlerinin bütünleşik olarak kullanıldığı bir uygulama yer almıştır. Performans değerlendirmesinde dikkate alınan kriterler literatür taraması ve yatırım uzman görüşleri dikkate alınarak belirlenmiştir. Finansal performans değerlendirme kriterlerinin önem ağırlıklarının hesaplanmasında objektif bir ağırlıklandırma yöntemi olan Entropi'den yararlanılmıştır. Herhangi bir sübjektifliğe yer vermeden, yalnızca işletmelerin finansal tablolarından elde edilen verilerden yararlanan Entropi yöntemi ile oldukça önemli olan kriterlerin önem ağırlıklarının belirlenmesi süreci tamamlanmıştır. Kriterlerin önem ağırlıkları dikkate alındığında, en önemli kriterlerin temettü verimliliği, özsermaye karlılı̆̆ı ve piyasa katma değeri olduğu belirlenmiştir.

Daha sonra Gri İliş̧isel Analiz yöntemiyle BIST menkul kıymet yatırım ortaklığı endeksinde yer alan işletmeler, finansal performanslarına göre sıralanmıştır. Finansal performansı en yüksek işletme İş Yatırım Ortaklığı olarak tespit edilmiştir. İş Yatırım Ortaklığını sırasıyla, Atlas Menkul Kıymetler Yatırım Ortaklığ1 ve Oyak Yatırım Ortaklığı takip etmiştir. Uygulama sonuçları Entropi ve Gri İlişkisel Analiz yöntemlerinin bütünleşik olarak uygulandığı bu yöntemin finansal performansın değerlendirilmesinde kullanılabileceğini göstermiştir. İş Yatırım Ortaklığı ile Atlas Menkul Kıymetler Yatırım Ortaklığı'nın, uygulama yapılan dönem içerisinde en önemli kriterler olarak belirlenen temettü verimliliği ve özsermaye karlılığ açısından en iyi durumda olmalarının, finansal performansı en yüksek olan iki işletme olarak öne çıkmalarında etkili olduğu görülmüştür.

$\mathrm{Bu}$ bağlamda menkul kıymet yatırım ortaklığı endeksinde yer alan işletmeler içinde finansal performansı düşük olan işletmelerin, temettü politikaları ve özsermaye karlılık durumlarını gözden geçirip, bu noktalarda çözüme yönelik adımlar atmaları konusunda önerilerde bulunulabilir. 
Akademik olarak ise, gelecek çalışmalarda farklı sektörlerde yer alan işletmeler için, ele alınan sektörün yapısına da uygun olacak şekilde belirlenen kriterlere göre, daha farklı ÇKKV yöntemleri ile finansal performans değerlendirmeleri yapılabilir. Ayrıca mevcut çalışmanın uygulamasında yer alan BIST menkul kıymet yatırım ortaklığı endeksindeki işletmelerin performansları daha farklı finansal performans kriterlerine göre ya da diğer ÇKKV yöntemleri kullanılarak değerlendirilebilir. Böylece elde edilen sonuçların birbirleri ile karşılaştırılması mümkün olacaktır.

\section{KAYNAKÇA}

AKÇAKANAT, Ö., EREN, H., AKSOY, E., ÖMÜRBEK, V. (2017), "Bankacılık Sektöründe Entropi ve WASPAS Yöntemleri İle Performans Değerlendirmesi”, Süleyman Demirel Üniversitesi Íktisadi ve İdari Bilimler Fakültesi Dergisi, 22(2), 285-300.

AKYÜZ, Y., BOZDOĞAN, T., HANTEKIN, E. (2011), “TOPSIS Yöntemiyle Finansal Performansin Değerlendirilmesi ve Bir Uygulama”, Afyon Kocatepe Üniversitesi, İ̈BF Dergisi, 13(1): 73-92.

AYTEKIN, A., KARAMAŞA, Ç. (2017), “Analyzing Financial Performance of Insurance Companies Traded in BIST via Fuzzy Shannon's Entropy Based Fuzzy TOPSIS Methodology", Alphanumeric Journal, 5(1), 51-84.

BALEŽENTIS, A., BALEŽENTİS, T., MİSIŪNAS, A. (2012), “An Integrated Assessment of Lithuanian Economic Sectors Based on Financial Ratios and Fuzzy MCDM Methods", Technological and Economic Development of Economy, 18(1), 34-53.

BAYRAKDAROGLU, A., YALÇIN, N. (2012), Strategic Financial Performance Evaluation of the Turkish Companies Traded on ISE, Ege Akademik Bakış, 12(4), 529-539.

BÜLBÜL, S., KÖSE, A. (2011), “Türk Gıda Şirketlerinin Finansal Performansının Çok Amaçlı Karar Verme Yöntemleriyle Değerlendirilmesi”, Atatürk Üniversitesi İktisadi ve İdari Bilimler Dergisi 10. Ekonometri ve İstatistik Sempozyumu Özel Sayısl, 71-97. 


\section{E. AYÇIN}

CHANG, S. C., TSAI, P. H. (2016), “A Hybrid Financial Performance Evaluation Model for Wealth Management Banks Following the Global Financial Crisis”, Technological and Economic Development of Economy, 22(1), 21-46.

DENG, J. (1989), "Introduction to Grey System Theory", The Journal of Grey System, 1(1), 1-24.

DOĞAN, M. (2013), "Measuring Bank Performance with Gray Relational Analysis: The Case of Turkey", Ege Akademik Bakış, 13(2), 215-225.

ECER, F., GÜNAY, F. (2014), “Borsa İstanbul'da İşlem Gören Turizm Şirketlerinin Finansal Performanslarının Gri İlişkisel Analiz Yöntemiyle Ölçülmesi”. Anatolia: Turizm Araştırmaları Dergisi, 25(1), 35-48.

EGE, İ., YAMAN, S. (2018), TOPSIS ve MOORA Yöntemleri İle Ölçülen Finansal Performansın Pay Getirilerine Etkisi: BIST Çimento-Beton İşletmeleri Üzerine Bir Panel Veri Uygulaması, Al-Farabi Uluslararasl Sosyal Bilimler Dergisi, 2(1), 75-96.

ELITTAŞ, C., ELEREN, A., YILDIZ, F., DOĞAN, M. (2012), "Gri İlişkisel Analiz İle Sigorta Şirketlerinin Performanslarının Belirlenmesi, 16. Finans Sетровуити, 521-530.

ERDOĞAN, M., YAMALTDINOVA, A. (2018), "Borsa İstanbul'a Kayıtlı Turizm Şirketlerinin 2011-2015 Dönemi Finansal Performanslarının TOPSİS ile Analizi”, Optimum Ekonomi ve Yönetim Bilimleri Dergisi, 5(1), 19-36.

ERDOĞAN, N. K., ALTINIRMAK, S., KARAMAŞA, Ç. (2016). "Comparison of Multi Criteria Decision Making (MCDM) Methods with Respect to Performance of Food Firms Listed in BIST", Copernican Journal of Finance \& Accounting, 5(1), 67-90.

ERGÜL, N. (2014), "BIST-Turizm Sektöründeki Şirketlerin Finansal Performans Analizi”, Çankırı Karatekin Üniversitesi İIBF Dergisi, 4(1), 325-340. 
EROL, I., FERRELL JR, W. G. (2009), “Integrated Approach for Reorganizing Purchasing: Theory and a Case Analysis on a Turkish Company", Computers \& Industrial Engineering, 56(4), 1192-1204.

ERTUĞRUL, İ., KARAKAŞOĞLU, N. (2009), "Performance Evaluation of Turkish Cement Firms with Fuzzy Analytic Hierarchy Process and TOPSIS Methods", Expert Systems with Applications, 36(1), 702-715.

ESBOUEİ, S. K., GHADIKKOLAEİ, A. S., ANTUCHEVİCiENE, J. (2014), "Using FANP and Fuzzy VIKOR for Ranking Manufacturing Companies Based on Their Financial Performance", Economic Computation \& Economic Cybernetics Studies \& Research, 48(3), 141-162.

GÖK-KISA, A. C., PERÇİN, S. (2018), "Bütünleşik Entropi Ağırlık-VIKOR Yöntemi İle Bilişim Teknolojisi Sektöründe Performans Ölçümü”. Ekonomik ve Sosyal Araştırmalar Dergisi, 14(1), 1-13.

GÜNAY, F., KARADENIZ, E., DALAK, S. (2018), “Türkiye'de En Yüksek Net Satış Gelirine Sahip 20 Şirketin Finansal Performanslarının Gri İlişkisel Analiz Yöntemiyle İncelenmesi”, Ömer Halisdemir Üniversitesi İktisadi ve İdari Bilimler Fakültesi Dergisi, 11(2), 51-73.

HO, C. T., WU, Y. S. (2006), "Benchmarking Performance Indicators for Banks", Benchmarking: An International Journal, 13(1/2), 147-159.

HSU, C. I., WEN, Y. H. (2000), “Application of Grey Theory and Multi Objective Programming towards Airline Network Design", European Journal of Operational Research, 127(1), 44-68.

HSU, L. C., OU, S. L., OU, Y. C. (2015), “A Comprehensive Performance Evaluation and Ranking Methodology under a Sustainable Development Perspective, Journal of Business Economics and Management, 16(1), 74-92.

IGNATIUS, J., BEHZADİAN, M., MALEKAN, H. S., LALITHA, D. (2012), Financial Performance of Iran's Automotive Sector based on PROMETHEE II, Proceedings of the 2012 IEEE ICMIT, 11-13 June, 2012, 35-38. 
İÇ, Y. T., TEKİN, M., PAMUKOĞLU, F. Z., YILDIRIM, S. E. (2015), "Kurumsal Firmalar İçin Bir Finansal Performans Karşılaştırma Modelinin Geliştirilmesi”, Gazi Üniversitesi Mühendislik-Mimarlık Fakültesi Dergisi, 30(1), 71-85.

İSLAMOGLU, M., APAN, M., ÖZTEL, A. (2015), “An Evaluation of the Financial Performance of REITS in Borsa Istanbul: A Case Study Using the Entropy-Based TOPSIS Method", International Journal of Financial Research, 6(2), 124-138.

KARAOĞLAN, S., ŞAHIN, S. (2018). BİST XKMYA İşletmelerinin Finansal Performanslarının Çok Kriterli Karar Verme Yöntemleri İle Ölçümü ve Yöntemlerin Karşılaştırılması. Ege Academic Review, 18(1), 63-80.

KAZAN, H., ERTOK, M., CÍFTÇİ, C. (2015), "Application of a Hybrid Method in the Financial Analysis of Firm Performance", Procedia-Social and Behavioral Sciences, 195, 403-412.

KONAK, T., ELBİR, G., YILMAZ, S., KARATAŞ, B. M., DURMAN, Y., DÜZAKIN, H. (2018), "Borsa İstanbul'da İşlem Gören Tekstil Firmalarının TOPSIS ve MOORA Yöntemi ile Analizi”, Çukurova Üniversitesi İ̈BF Dergisi, 22(1), 11-44.

KUNG, C. Y., YAN, T. M., CHUANG, S. C. (2006), "GRA to Assess the Operating Performance of Non-Life Insurance Companies in Taiwan", The Journal of Grey System, 18(2), 155- 160.

KUNG, J. Y., CHUANG, T. N., KY, C. M. (2011), “A Fuzzy MCDM Method to Select the Best Company Based on Financial Report Analysis", IEEE International Conference on Fuzzy Systems, 27-30 June, 2011, Taipei, Taiwan, 2013-2017.

LEE, P. T. W., LIN, C. W., SHIN, S. H., (2012), “A Comparative Study on Financial Positions of Shipping Companies in Taiwan and Korea using Entropy and Grey Relation Analysis”, Expert Systems with Applications 39(5), 5649-5657. 
LIN, J. L., LIN, C. L. (2005), "The Use of Grey-Fuzzy Logic for the Optimization of the Manufacturing Process", Journal of Materials Processing Technology, 160(1), 9-14.

MANDIC, K., DELIBASIC, B., KNEZEVIC, S., BENKOVIC, S. (2014), "Analysis of the Financial Parameters of Serbian Banks through the Application of the Fuzzy AHP and TOPSIS Methods", Economic Modelling, 43, 30-37.

ORÇUN, Ç., EREN, B. S. (2017), “TOPSIS Yöntemi ile Finansal Performans Değerlendirmesi: XUTEK Üzerinde Bir Uygulama”, Journal of Accounting \& Finance, (75), 139-154.

ÖMÜRBEK, N., EREN, H. (2016), "PROMETHEE, MOORA ve COPRAS Yöntemleri İle Oran Analizi Sonuçlarının Değerlendirilmesi: Bir Uygulama", Mehmet Akif Ersoy Üniversitesi Sosyal Bilimler Enstitüsü Dergisi, 8(16), 174-187.

ÖMÜRBEK, N., KARAATLI, M., BALCI, H. F. (2016), "Entropi Temelli MAUT ve SAW Yöntemleri ile Otomotiv Firmalarının Performans Değerlemesi”, Dokuz Eylül Üniversitesi İktisadi ve İdari Bilimler Fakültesi Dergisi, 31(1), 227255 .

ÖMÜRBEK, N., MERCAN, Y. (2014), "İmalat Alt Sektörlerinin Finansal Performanslarının TOPSIS ve ELECTRE Yöntemleri İle Değerlendirilmesi”, Çankırı Karatekin Üniversitesi İ̈BF Dergisi, 4(1), 237-266.

ÖNDER, E., ALTINTAŞ, A. T. (2017), "Financial Performance Evaluation of Turkish Construction Companies in Istanbul Stock Exchange (BIST)", International Journal of Academic Research in Accounting, Finance and Management Sciences, 7(3), 108-113.

ÖZDAĞOĞLU, A., YAKUT, E., BAHAR, S. (2017), "Machine Selection in a Dairy Product Company with Entropy and SAW Method Integration”, Dokuz Eylül Üniversitesi İktisadi ve İdari Bilimler Fakültesi Dergisi, 32(1), 341-359.

ÖZDEN, U. H., BAŞAR, O. D., KALKAN, S. B. (2012), "IMKB'de İşlem Gören Çimento Sektöründeki Şirketlerin Finansal Performanslarının VIKOR 
Yöntemi İle Sıralanması", Istanbul University Econometrics and Statistics eJournal, 17(1), 23-44.

PEKER, İ., BİRDOĞAN, B. (2011), “Gri İlişkisel Analiz yöntemiyle Türk Sigortacılık Sektöründe Performans Ölçümü”. Uluslararası İktisadi ve İdari Incelemeler Dergisi, 4(7), 1-17.

SAFAEI GHADIKOLAEI, A., KHALILI ESBOUEI, S., \& ANTUCHEVICIENE, J. (2014), "Applying Fuzzy MCDM for Financial Performance Evaluation of Iranian Companies", Technological and Economic Development of Economy, 20(2), 274-291.

SALDANLI, A., SIRMA, İ. (2014), “TOPSIS Yönteminin Finansal Performans Göstergesi Olarak Kullanılabilirliği”, Marmara Üniversitesi Öneri Dergisi, 41: 185-202.

SEÇME, N. Y., BAYRAKDAROĞLU, A., KAHRAMAN, C. (2009), "Fuzzy Performance Evaluation in Turkish Banking Sector Using Analytic Hierarchy Process and TOPSIS” Expert Systems with Applications, 36(9), 11699-11709.

SERMAYE PIYASASI KURULU (SPK), (2016), "Menkul Klymet Yatırtm Ortaklıkları", www.spk.gov.tr ; Erişim Tarihi: 30/08/2018.

SHEN, K.Y., TZENG, G. H (2015), “A Decision Rule-Based Soft Computing Model for Supporting Financial Performance Improvement of the Banking Industry", Soft Computing, 19(4), 859-874.

TAYYAR, N., AKCANLI, F., GENÇ, E., EREM, I. (2014). “BIST’e Kayttlı Bilişim ve Teknoloji Alanında Faaliyet Gösteren İşletmelerin Finansal Performanslarının Analitik Hiyerarşi Prosesi (AHP) ve Gri İlişkisel Analiz (GİA) Yöntemiyle Değerlendirilmesi”, Muhasebe ve Finansman Dergisi, (61), 19-40.

TÜTÜNCÜ, L., UYSAL, Z. (2018), “Testing a Simple Financial Alternative to TOPSIS for Financial Performance Measurement", Muhasebe ve Finansman Dergisi, (78), 249-264. 
ULUDAĞ, A. S., ECE, O. (2018). “Türkiye'de Faaliyet Gösteren Mevduat Bankalarının Finansal Performanslarının TOPSIS Yöntemi Kullanılarak Değerlendirilmesi”, Finans Politik \& Ekonomik Yorumlar, 55(637), 49-80.

WANG, T. C., LEE, H. D. (2009), "Developing a Fuzzy TOPSIS Approach Based on Subjective Weights and Objective Weights", Expert Systems with Applications, 36(5), 8980-8985.

WANG, Y. J. (2008), "Applying FMCDM to Evaluate Financial Performance of Domestic Airlines in Taiwan”, Expert Systems with Applications, 34(3), 18371845 .

WANG, Y. J. (2009), "Combining Grey Relation Analysis with FMCGDM to Evaluate Financial Performance of Taiwan Container Lines", Expert Systems with Applications, 36(2), 2424-2432.

WANG, Y. J. (2014), "The Evaluation of Financial Performance for Taiwan Container Shipping Companies by Fuzzy TOPSIS", Applied Soft Computing, 22, 28-35.

WANG, Y. J., LEE, H. S. (2010), "Evaluating Financial Performance of Taiwan Container Shipping Companies by Strength and Weakness Indices", International Journal of Computer Mathematics, 87(1), 38-52.

WANKE, P., KALAM AZAD, M. A., BARROS, C. P., HADI-VENCHEH, A. (2016), "Predicting Performance in ASEAN Banks: An Integrated Fuzzy MCDMNeural Network Approach. Expert Systems, 33(3), 213-229.

WU, H. H. (2002), “A Comparative Study of Using Grey Relational Analysis in Multiple Attribute Decision Making Problems”, Quality Engineering, 15(2), 209217.

YILDIRIM, M., ALTAN, İ. M., GEMİCİ, R. (2018), "Kurumsal Yönetim İle Finansal Performans Arasındaki İlişkinin Entropi Ağırlıklandırmalı TOPSIS Yöntemi İle Değerlendirilmesi: BIST’te İşlem Gören Gıda ve İçecek Şirketlerinde 


\section{E. AYÇIN}

Bir Araştırma", Muhasebe ve Vergi Uygulamaları Dergisi (Muvu)/Journal Of Accounting \& Taxation Studies (Jats), 11(2), 130-152.

YILDIRIM, B. F., ÖNDER, E. (2015), "Çok Kriterli Karar Verme Yöntemleri”, 2. Bask1, Bursa: Dora Yayınc1lık.

YÜKÇÜ, S., KAPLANOĞLU, E. (2015), “Çok Kriterli Karar Verme Yöntemleriyle Gözaltı Pazarı Şirketlerinin Finansal Performanslarının Belirlenmesi”, World of Accounting Science, 17(3), 687-616.

ZHAI, L. Y., KHOO, L. P., ZHONG, Z. W. (2009), "Design Concept Evaluation in Product Development Using Rough Sets and Grey Relation Analysis", Expert Systems with Applications, 36(3), 7072-7079.

ZHANG, H., GU, C. L., GU, L. W., ZHANG, Y. (2011), "The Evaluation of Tourism Destination Competitiveness by TOPSIS \& Information Entropy-A Case in the Yangtze River Delta of China”, Tourism Management, 32(2), 443-451.

ZHANG, X., WANG, C., LI, E., XU, C. (2014). “Assessment Model of Eco environmental Vulnerability Based on Improved Entropy Weight Method", The Scientific World Journal, 1-7. 